\title{
EXISTENCE OF THE DISTINCTION PRINCIPLE AS A PROTECTION FOR THE VICTIMS OF ARMED CONFLICT: THE IMPLICATIONS ON RENEWAL OF THE NATIONAL LAW ${ }^{\Omega}$
}

\author{
Danial \\ Law Faculty of Sultan Ageng Tirtayasa University \\ E-mail: bontobangun@gmail.com
}

\begin{abstract}
This study intent to analyze the existence of the distinction principle in international humanitarian law can provide effective protection against combatants and civilians in a modern armed conflict and contribute to the protection of victims of internal conflicts in Indonesia. It is very important to find the concept of the protection of victims of internal conflict in Indonesia. This research uses a normative, and the research also applies a descriptive-analytical approach to examine and analyze the research questions of the thesis. In doing so, this research uses a secondary data, these legal materials are subsequently analyzed using a qualitative juridical approach. The results showed that the existence of distinction principle at the level of concepts and implementations provide less effective protection against combatants and civilians in modern armed conflict. And the contribution of distinction principle to the protection of victims of internal conflicts in Indonesia is able to strengthen the concept of "sishankamrata" and national legislation.
\end{abstract}

Keywords: armed conflict, distinction principle, protection of victim.

\begin{abstract}
Abstrak
Studi ini dimaksudkan untuk mengkaji eksistensi prinsip pembedaan dalam hukum humaniter internasional agar dapat memberikan perlindungan efektif terhadap kombatan dan penduduk sipil dalam konflik bersenjata modern dan pengaruhnya terhadap upaya perlindungan korban konflik internal di Indonesia. Hal ini sangat penting untuk menemukan konsep perlindungan korban konflik internal di Indonesia.Penelitian ini menggunakan metode yuridis normatif dan bersifat deskriptif analitis, yaitu menganalisis identifikasi masalah dengan menggunakan data sekunder, kemudian dianalisis secara yuridis kualitatif. Hasil penelitian menunjukkan bahwa Eksistensi prinsip pembedaan dalam tataran konsep dan implementasi kurang memberikan perlindungan efektif terhadap kombatan dan penduduk sipil dalam konflik bersenjata modern. Selain itu, kontribusi prinsip pembedaan terhadap upaya perlindungan korban konflik internal di Indonesia dapat memperkuat konsep sishankamrata dan peraturan perundang-undangan nasional.
\end{abstract}

Kata Kunci: konflik bersenjata, prinsip pembedaan, perlindungan korban.

\section{Preface}

The distinction principle is a division of population in a country which are involved in an armed conflict into two groups, they are combatant and civilian. According to Pietro Verri, the need for the distinction between combatants and civilians is to find out the people who are allowed to a hostilities, there-fore it could be as

$\Omega$ This research is funded by DP2M Dikti with the number

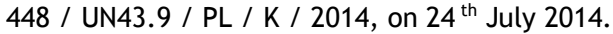

Eric Talbot Jensen, "Combatant Status: It is Time for Intermediate Levels of Recognition for Partial the violence objects and for those who are not participate in hostilities should not be used as a target or object of violence. Thus, the essence of the distinction principle basically is to give the limitation to combatants who are involved in an armed conflict and give the protection for the civilians. $^{1}$

compliance", Virginia Journal of International Law, Vol. 46 2006, Virginia USA: Virginia University Publishing, page 23 
The rules of the distinction was attached in the Den Haag Congress in 1907 and in the $1^{\text {st }}$ $4^{\text {th }}$ Jenewa Conventions in 1949 and also in their Additional Protocols. The term of com-batants in the $1^{\text {st }}$ Additional Protocol explicitly stated in a Law Section 43 paragraph 2, which explicitly determine that they can be classified as combatants are those who are included in the meaning of the armed forces of a country, and those who are included in the meaning of that armed forces is 'those who have right to directly participate in hostilities' they are con-sists of an organized armed forces. ${ }^{2}$

The rules of the combatants, especially the one which is regulated in a Law Section 43 paragraph 2 and in Law Section 48 of $1^{\text {st }}$ Additional Protocol in 1977 above has not touched the substance of distinction principle and has not been effective yet, both in the terms of setting and in the terms of implementation, it is happens because: first, There is a difference interpretation of the distinction principle of international humanitarian law; second, The difficulty to differentiate between the combatants and uncombatants in today's modern armed conflict; third, The development forms of a conflict that had only international armed conflict then appear a non-international armed conflict; as well as there is a differences between the norms of $1^{\text {st }}$ and $2^{\text {nd }}$ Additional Protocol in 1977.

The differences in regulation, interpretation, norms, obligations of states in international and non-international conflicts, also the development in form of an armed conflict highly influence the implementation, especially the particular rules to a part which is not involved and no longer involved in the armed conflict, and the protection of civilians. Therefore, every single country in this hole world can declare a war because of various reason as well as the US military aggression in Afghanistan. This is a proof of the weakness of international humanitarian law and the relevance of the distinction principle in today's modern armed conflict.

Danial, "Hukum Humaniter Internasional; Perbandingan Antara Islam dan Barat", Al Qalam: Religious and Social Journal, Vol. 26, No. 2 May-August 2009, Serang: Rese-
Indonesia as a country which is ratified the international humanitarian law should implement the international treaties that have been ratified. Therefore, to ensure the implementation of the results of the agreement, Indonesia in the state implementation and administration is arrange within a system of legislation as a form of strengthening the international humanitarian law. Based on that, for researchers this became the motivation and consideration to write this paper.

\section{The Issues}

Based on the description above, it can be formulated to the problem: first, How does the distinction principle of international humanitarian law provide an effective protection against the combatants and the civilians in a modern armed conflict?; second, How far the contribution of the distinction principle of international humanitarian law related with the protection of internal conflict victims in Indonesia?

\section{Research Methods}

This research uses normative juridical approach, with the approach of general principles of law and the historical approach. This research is categorized as a descriptive analytic research, which is searching for a data or images as accurately as possible related with the main of the problem. Those pictures are collected from the existing facts and objectively analyzed the terms of war regulation in the $4^{\text {th }}$ Convention of Jenewa in 1949, international practices and the implementation in anticipating the occurrence of armed conflict and also minimizing the casualties because of the armed conflict. The specifications of this research is a juridical normative which is legal research using the secondary data sources.

Analysis which is used in this research is a qualitative analysis, means that this analysis will not use the formulation numeric but the analysis has more phenomenological character. because of the analysis from the data qua-litative is not

arch Institute of the Islamic State Institute of Sultan Maulana Hasanuddin Banten, page 213-228. 
using calculation method but by explaination and depiction of all of the entire problems researched describe more.

\section{Discussion}

\section{The Distinction Principle as an Effective Pro-} tection Effort to the Armed Conflict Victims

International humanitarian law is a branch of international law which provide the protection and restrictions use of violence in armed conflict against: ${ }^{3}$ first, those who do not or no longer participating directly in hostilities; second, a restrictions on the number of facilities used to achieve the goal of the conflict, which is weakens the potential of enemy's military. Based on all of those thing above can be concluded that the basic principles of international humanitarian law, including: ${ }^{4}$ the difference between the civilians and combatants; a prohibition to attack those who are hors de combat; a prohibition which cause an unnecessary suffering; the necessity principle, and the proportionality principle.

The distinction principle is basically differentiate a legitimate targets (military objects) and an illegitimate targets (civilian objects). It is a forbidden thing in a war to make civilian objects as the target, while the military objects can be the target of the attack. Basically there is no definition of civilian property in international humanitarian law. Therefore, the definition of military object is to determine what is the meaning of civilian object. Law Article 52-2 of $1^{\text {st }}$ Additional Protocol provides a definition of military targets is "The military targets are limited for those objects which by their characteristic, location, purpose or its use give an effective contribution for military action which if its destroyed completely or partially, captured or neu-

3 lan Handerson, "The Contemporary Law of Targeting", Martinus Nijhoff Publisher Journal, Vol. 25 2009, Leiden-Boston: Hotei Publishing, page 326.

4 T.C.W. Blanning, "The Culture of Power and the Power of Culture". Oxford University Journal, Vol. 62, 2005, Oxford: Oxford University.

5 Manfred Lachs, "Thought On Science, Tecnology An World Law", AJIL, Vol 86, No.4, October 1992, page 6574; look also in Mark David, Max Maxwell and Sean M. Watts, "Unlawful Enemy Combatant: Status, Theory of Culpability, or Neither?" Journal of International Crimi- tralized, in the circumstances prevailing at that time, provide a real military advantage. So, there are two criteria to identify the military targets: ${ }^{5}$ the characteristic, place, purpose, or use of objects should contribute effectively to a military action; an object destruction, capture, or neutralization are has very effective contribution to the military action

Therefore, every doubts about whether an object is a civil or military object, and if the object usually used for civilian purposes, then the war parties should assume that the object is a civilian object and can not be the targeted for an attack (Law Article 52.3 of $1^{\text {st }}$ Additional Protocol). If one of the parties decides to attack, then the attack must be a legitimate attack. The Attacker must be able to prove that the object is used for military purposes. The military commander must take a pre-cautions before and on the time of the attack to protect the civilian and the civilian objects. ${ }^{6}$

A Precautions before the attack can be done by selecting the tools and methods of attack, keeping in mind to avoid, and in any case to reducing, an unnecessary thing such as losing the civilian because of deaths, the civilians who get injury and the damage of the civilian objects. ${ }^{7}$ Whereas the precautions at the time attack is that an attack must be canceled or suspended if it becomes apparent that the target is not a military object or it have special protection or that the attack is expected to cause an unnecessary losses in the form of civilian deaths, the civilians injury, the broken of the civilian objects, or the combination of all of it, it is an excessive real act compared to the real military advantages and directly which are intended. Beside, an effective preliminary warning must be given to the attacks which could make a harmful

nal Justice, Vol. 1, 2007, London: Greenwood Publishing Group. Inc, page 18-27.

6 Look in Article 57 Additional Protocol I in 1977; also in Schmitt, Michael, "Humanitarian Law and Direct Participation in Hostilities by Private Contractors or Civilian Employees", Chicago Journal of International Law, Vol. 156 2004, Chicago: Chicago University, page 634-650.

7 Waldemar Solf, 'Protection of Civilians Against the Effects of Hostilities under Customary International Law and under Protocol I, (1986) American University Journal of International Law and Policy 117, chapter 2, Arizona USA: American Indian College Publishing, page 80-89. 
things to the civilians unless when the circumstances is not permited. However, even though the target is a legitimate target, the propotional principle should be implemented. ${ }^{8}$

The proportional principle means that the damage which will be suffered by the civilians or civilian objects must be proportional in the characteristic and do not excessive in the term of gained the real and direct military advantage which is foreseeable the consequence of an attack on military targets. It should be emphasized that the means of proportional here is not a balance. As an illustration, to destroy two enemy with machine guns, it does not need to be deployed one cavalry division of tanks, be-cause it is not only can destroy those enemies, but it also can destroy the civilian population and civilian objects around it or its often called as the collateral damage. Collateral damage is an accidental damage because of the target of the attack is the military object also cause a damage to the civilian objects. ${ }^{9}$

Therefore, international humanitarian law decide that the distinction principles and proportionality principle must be on the same goal. According to the proportional principle, "the effect which is produced by the means and methods of war which are used in a specific situations should be proportional to the advantage military that achieved. ${ }^{10}$ Basically to do an attack is not a prohibition by the International humanitarian, but the one which is prohibited is the indiscriminate attack. Law Article 57 paragraph 1 of the $1^{\text {st }}$ Additional Protocol of 1977 states that during an international conflict, a continuous attention must be given to save the civilian population, civilians and civilian objects. While in an armed conflict and in non-international armed conflict, $2^{\text {nd }}$ Additional Protocol provides minimal protection which is states that civilians "shall enjoy the general protection

\footnotetext{
Ibid

9 Robert D Crane, "The Essence of Islamic Law", The Journal Islamic Law, Fall/Winter, Vol. 3, 1998, New 10 York: Valgrave Macmillan Publishing, page 23-33.

10 Ibid

11 Article 13 Additional Protocol II in 1977; Jennie Magnusson, "A Question of Definition and Concept of Internal Armed Conflict in the Swedish Aliens Act", European Journal of Migration and Law, No. 10 Vol. 50, 2008.
}

against the dangers which is arising from the military operations" and "will not be the object of the attack. "2 $2^{\text {nd }}$ Additional Protocol also prohibits an acts or threats of violence, which the primary purpose is "to spread the terror among the civilian population. ${ }^{11}$

The Armed conflict both the international and non-international, distinction and proportionality principle should be run simultaneously. This is because there is no obligation for the military to respect the distinction between the combatants and non-combatants. Michael Walzer pointed the aerial bombardment by the France air force during the World War II against the German military objects. ${ }^{12}$ The difficulties experienced by the pilot is to destroying military objects without causing a damage to the farms around the areas. The consequence is that in every attack will lead to the victim, but the victim must be minimized. Pilots can use its expertise to fly as low as possible to detecting the object of attack. During the aerial bombardment, sometimes it is very difficult for a pilots to fly as low as possible to target the military objects. The consequently, some civilians can become a victim of that attack.

The Contributions Distinction Principle of International Humanitarian Law Against Legal Reform of National Law As the Protection Effort of the Internal Conflict Victims in Indonesia.

An internal armed conflict is an armed conflict which is occured in the State. There are several definitions of the internal armed conflict which is given by the experts, there are the definitions which is given by Pietro Verri:

A non-international armed conflict is a combat between the armed forces af a state and dissident or rebel armed forces ... However, a conflict in the territory of a state between two ethnic group may be

12 Michael Walzer, 2000, Just and Unjust Wars, $A$ Moral Argument with Historical Illustrations, 3rd ed, New York: Basic Books, page 157; in Mark David, Max Maxwell and Sean M. Watts, "Unlawful Enemy Combatant: Status, Theory of Culpability, or Neither?” Journal of International Criminal Justice, Vol. 1, 2007, London: Greenwood Publishing Group.Inc, page 150. 
classed as a non-international armed conflict provided it has the necessary characteristics, duration and participation. ${ }^{13}$

The Pietro Verri's view above, shows that the characteristics of a non-international armed conflict is a battle between the armed forces of a State with the armed forces of the rebels or the dissidents. However, an armed conflict which is occurred in the State between two ethnic groups can be regarded as an international armed conflict with the terms in completed the requirements of intensity, the duration and participation (the parties which are in the conflict).

An Armed conflict became an international armed conflict or is called internationalized internal armed conflict, occurs when a foreign country providing its military assistance to armed groups fighting the government in a State. Example: the situation in Afghanistan when the Taliban government in lead the states, which the United States and other countries providing the military assistance to the Hamid Kharzai Group to overthrow the Taliban. ${ }^{14}$ Another example is the armed conflict between the Israel and Palestine which is an international armed conflict, as well as armed conflict between Thailand and Cambodia. Two examples of such an armed conflict involving one to another State. Armed conflict can also occur and involve many countries, another example of an armed conflict which is involving by many countries is a war which is involving the multilateral forces under the command of US forces against Iraq. ${ }^{15}$

Internal armed conflict occurs several times in Indonesia. History of the Indonesian since the proclamation of independence on August 17, 1945 is highlighted by many various of conflict, both vertical and horizontal conflicts. ${ }^{16}$ There are several reasons which is makes the occur-

13 Michael Schmitt, "The Principle of Discrimination in 21st Century Warfare", Yale Human Rights \& Development Law Journal, 1999, Jeneva: ICRC, page 33-40.

14 Ibid

15 Paul Orogun, “Blood Diamonds And Africa's Armed Conflicts in the Post-Cold war Era (2004)", World Affairs Journal, Vol. 166 No. 3

16 Vertical conflict is an internal conflict between the government against groups of people, while the horizontal rence of an internal conflict between the government and the community groups. Some conflicts have occurred in Indonesia, for example the Rebellion of $\mathrm{G} 30 \mathrm{~S} / \mathrm{PKI}$, The Rebellion of RMS (Republik Maluku Selatan), PRRI, Kahar Muzakkar rebellion, up-rising DI TII (Darul Islam Tentara Islam Indonesia), and the rebellion of OPM (Organisasi Papua Merdeka). ${ }^{17}$

Those conflicts were resolved by the government by deployment of police and/or the military which causing the casualties, both on the part of government officials and the public. For example, the operations which performed to resolve the internal conflicts in Aceh, Papua and Timor Timur, where the intensity of the use of police and military officers are more huge, which causing the casualties, both for the authorities and society. Another consequence of the use of police and military in addressing security threats and internal conflicts are violations of the law, either in the form of human rights abuses and the violations of international humanitarian law. ${ }^{18}$

Indonesia as part of the international community in the ratification of international law strongly considering the national interests. As one of the 194 countries which have ratified the Jenewa Convention in 1949 through Law No. 59 In 1958, Indonesia has an obligation to implemented the provisions of humanitarian law into the national legislation. The International law, set up the mobilization specifically, but the understanding of the concept of mobilization can be traced through the problems which associated with the militia, levee en masse and the civil defense, mainly associated with their status in the battle. Levee en masse militia is defined as the civilians who bring the arms and carry it openly and also it is able to respect the law and the customs of war, there-fore their status is as

conflicts are internal conflicts that occur between groups of people from one to another.

17 Natsri Anshari, "Tanggung Jawab Komando Menurut Hukum Internasional dan Hukum Nasional Indonesia", Humanitarian Law Journal, Vol. 1 No. 1, July 2005. Jakarta: Trisakti,

18 Rizanizarli, “Hukum Humaniter Internasional dan Hubungannya dengan Hak Asasi Manusia", Journal of Kanun Law Studies, Vol. XI No. 29, Agustus 2001, Aceh: FH Unsyiah, page 25 . 
the combatants. While the civil defence in the terms of humanitarian law is a civilians group who are not involved as the participants in combat, but more specifically it is more on the tasks of protect the public from the consequences of the battle.

The National provisions on the implementation of Law Article 30 UUD 1945 which is associated with the legal humaiter arrangements can be started from the UU.No. 3 of 2002 about the National Defence which is arrange the country's defence system in the term of facing the military threat, makes the Indonesian National Army as the main component, supported by the reserve components and supporting components. The Reserve component, consisting of citizens, natural resources, artificial resources, and also the national infrastructure that has been prepared for mobilization to enlarge and strengthen the main component. While as the supporting components, are consists of the citizens, natural resources, artificial resources, and also the national infrastructure which directly or indirectly increase the strength and ability of the main components and the planned components.

According to the draft of national law of national defence reserve component (nowadays referred as the RUU KCPN), in a normal circumstances in a peace, the components members, the elements of natural resources, artificial resources, national infrastructure as well as members are specified in the active service as an assignment for over 30 (thirty) days in every year, to have a training. While in a state of an emergency millitary condition or a condition after a war the mobilized reserve the assignment component status as the combatants. ${ }^{19}$

Such an obligatory provisions, if its studied further will cause the problems, especially which is associated with the regulation of international humanitarian law. One of the principles which is underlying the implementation of the

19 Article 29 RUUKCPN

20 Already described in the previous chapter that combatants are those who may actively participate in the battle, when the opponent caught a war prisoner civil. Civilian are those who do not (should) take part in the battle, they should be protected and should not be targeted attack. humanitarian law is the distinction principle. This principle implies that in an armed conflict, a population groups are divided into two groups, they are: the combatant and civilian. ${ }^{20}$

The law Article of 30 is a national regulation of the national defence and its implementation are also applicable in the territory of Indonesia. Things will be different when Indonesia is involved in an armed conflict with another state. The International relations which is involving the international community members, change rapidly, initially from the level of a good relationship (a harmonic relationship) becoming strained because of a problem. It can also occur, sometimes there is a threat from other countries, because basically the characteristic of the threat can not be suspected in time, place and shape. The problem solving with other nations as can as possible through the peace way.

Therefore, the protection of humanitarian principles which is set out by the Human Rights and international humanitarian law is to contribute the development of Indonesian national laws in particular legislation especially the law of governing the humanitarian principles. Law No. 39 of 1999 on Human Rights as one of the laws which is promote the humanitarian principles affirmed that human rights are a set of rights which attached to the nature and the existence of human beings as the creatures of God Almightly and His is a gift which must be respected, a high respected and it must be protected by the state, law, government, and everyone for the respect and protection of human dignity. The same thing also stated by Manfred Nowak with descriptive approach, legal and philosophical, that Nowak is asserts that the focus of human rights is a matter of life dignity of human beings. ${ }^{21}$

\section{Closing \\ Conclusion}

21 Already described in the previous chapter that combatants are those who may actively participate in the battle, when the opponent caught a war prisoner civil. Civilian are those who do not (should) take part in the battle, they should be protected and should not be targeted attack. 
The existence of the distinction principle of the international humanitarian law at the level of concepts and implementations provides less effective protection against the combatants and the civilians in a modern armed conflict. It is influenced by the development of forms of a conflict, which first is only the international armed conflicts then the non-international armed conflict is followed; the differences between the norm of $1^{\text {st }}$ and $2^{\text {nd }}$ Additional Protocol in 1977; the differences in the interpretation of the object; and also the difficulty to differenciate between the combatants and non-combatants in today's modern warfare.

The contributions of distinction principle of international humanitarian law in the term of protection victims of the internal conflict in Indonesia, can strengthen the security and defence concepts and the humanitarian treatment principles which is contained in the national legislation related to the defend of the country.

\section{Suggestion}

An implementation action of international humanitarian law needs to be done in the terms of the protection to the victims of war and the civilians due to the armed conflict, the Government of Indonesia through the foreign ministry should encourage the UN Security Council to act decisively, and to be fair to the countries which are violate the provisions of international humanitarian law. In addition, Indonesia needs to ratify the instruments of international humanitarian law in terms of the protection of victims of an armed conflict. But still have to consider the national interest.

\section{Bibliography}

Anshari, Natsri. “Tanggung Jawab Komando Menurut Hukum Internasional dan hukum $\mathrm{Na}$ sional Indonesia”. Humanitarian Law Journal, Vol. 1 No. 1, July 2005. Jakarta: Trisakti;

Blanning, T. C. W. "The Culture of Power and the Power of Culture." Oxford University Journal, Vol. 62, 2005. Oxford: Oxford University;

Crane, Robert D. "The Essence of Islamic Law". The Journal Islamic Law. Fall/Winter. Vol
3. 1998. New York: Valgrave Macmillan Publishing;

Danial. "Hukum Humaniter Internasional: Perbandingan Antara Islam dan Barat”. Jurnal Keagamaan dan Kemasyarakatan Al Qalam, Vol. 26. No. 2, May-August 2009. Banten: Research Institute of The Islamic State Institute of Sultan Maulana Hasanuddin;

David, Mark., Max Maxwell and Sean M. Watts, "Unlawful Enemy Combatant: Status, Theory of Culpability, or Neither?". Journal of International Criminal Justice, Vol. 1, 2007. London: Greenwood Publishing Group. Inc;

Handerson, Ian. "The Contemporary Law of Targeting”. Martinus Nijhoff Publisher Journal, Vol. 25, 2009. Leiden-Boston: Hotei Publishing;

Jensen, Talbot Eric. "Combatant Status: It is Time for Intermediate Levels of Recognition for Partial compliance". Virginia Journal of International Law, Vol. 46. 2006. Virginia USA: Virginia University Publishing;

Magnusson, Jennie. “A Question of Definition and Concept of Internal Armed Conflict in the Swedish Aliens Act". European Journal of Migration and law, Vol 50. No. 102008. Swedia: Sweden University Publishing;

Orogun, Paul. "Blood Diamonds And Africa's Armed Conflicts in the Post-Cold war Era". World Affairs Journal, Vol. 166 No.3 2004. in Jean Marie Henckaerts and Louis Doswald Beck (ed). "Customary International Humanitarian Law”. International Humanitarian Journal, Vol. II, 2005. New York. Cambridge University Press;

Rizanizarli. "Hukum Humaniter Internasional dan Hubungannya dengan Hak Asasi Manusia”. Journal of Kanun Law Studies, Vol. XI No. 29 August 2001. Aceh: Law Faculy of Unsyiah;

Schmitt, Michael. "Humanitarian Law and Direct Participation in Hostilities by Private Contractors or Civilian Employees". International Law of Chicago Journal, Vol. 156. 2004. Chicago: Chicago University;

Schmitt, Michael. "The Principle of Discrimination in 21st Century Warfare". Yale Human Rights \& Development Law Journal. Vol. 143, 1999. Jeneva: ICRC Publishing;

Solf, Waldemar. "Protection of Civilians Against the Effects of Hostilities under Customary International Law and under Protocol I". American University Journal of Inter- 
national Law and Policy, Vol. 117, 1986.

Arizona USA: American Indian College Publishing;

Yuliantiningsih, Aryuni. "Perlindungan Terhadap Pengungsi Domestik Menurut Hukum Humaniter HAM". Jurnal Dinamika Hukum, Vol. 8 No. 3 September 2008. Purwokerto: Law Faculty of Jenderal Soedirman University. 